\title{
Gertrude Stein Oyunlarında Karşı-Anlatı Stratejileri
}

\section{Anti-Narrative Strategies in the Plays of Gertrude Stein}

\author{
Melike Saba Akım ${ }^{1}$ (1)
}

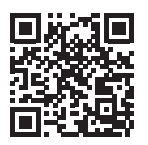

\footnotetext{
*Bu makale 2019 ylında İstanbul Üniversitesi Sosyal Bilimler Enstitüsü Tiyatro Eleştirmenliği ve Dramaturji Anabilim Dalı́nda tamamladığım "Tarihsel Avangard Sonrası Dram Sanatında Karşı-anlatı" başlıklı doktora tezinden hareketle hazırlanmıştır.
}

'Doktor Öğretim Üyesi, Maltepe Üniversitesi, Güzel Sanatlar Fakültesi, Sahne Sanatları Bölümü, Istanbul, Türkiye

\section{ORCID: M.S.A. 0000-0003-2275-237X}

Sorumlu yazar/Corresponding author: Melike Saba Akım,

Maltepe Üniversitesi, Güzel Sanatlar Fakültesi, Sahne Sanatları Bölümü, İstanbul, Türkiye E-posta/E-mail: melikesaba@gmail.com

Başvuru/Submitted: 22.02 .2020 Revizyon Talebi/Revision Requested: 12.04.2020

Son Revizyon/Last Revision Received: 24.04.2020

Kabul/Accepted: 27.04 .2020

\section{Atıf/Citation:}

Saba-Akim, Melike. "Gertrude Stein Oyunlarında Karşı-Anlatı Stratejileri" Tiyatro Eleştirmenliğive Dramaturji Bölümü Dergisi 30, (2020): 71-98. https://doi.org/10.26650/jtcd.692767

\section{öz}

Tiyatro söz konusuysa, 1970'li yılların düşünsel atası Tarihsel Avangard döneme bakınca iki isim özellikle öne çıkar: Kıta Avrupası'nda "akılcı söz" logosa, bu yüzden de metine itiraz eden Antonin Artaud, Amerika kıtasındaysa ilk oyunu What Happened'ı [Ne Oldu] yazarken Batı tiyatrosuna sımsıkı bir kemerle eklemlenmiş logosu, metini dışlamadan reddetmeyi deneyen Gertrude Stein. 1970'li yılların deneysel tiyatro girişimleri, tiyatrodan metini topyekûn dışlamış değildir: Robert Wilson'dan Richard Foreman'a deneysel tiyatro ya da Sarah Kane'den Martin Crimp'e yeni metinsellik, sözün ve yazının özgül ağırlığını başkalaştırmış; böylece hem tiyatro hem de performans klasik tanımlarının dışına taşan bir melezlenme açığa çıkarmıştır. Bu yazıda, metini dışlamak yerine konvansiyonel anlatı tanımının mutlak koşulu "olaylar dizgesi"ni tiyatrodan kaldırmayı deneyen Gertrude Stein oyunlarının karşı-anlatısal stratejilerini örneklemek amaçlanmaktadır.

Anahtar Kelimeler: Gertrude Stein, Karşı-Anlatı, Peyzaj Metin, Dramatik Yapı, Postdramatik

\section{ABSTRACT}

When theatre in general is taken into consideration, two pioneers particularly stand out in the Historical Avant-Garde period and they can be seen as intellectual ancestors of the 1970s: Antonin Artaud from Continental Europe who objected to the "rational word" logos and therefore to the text; and Gertrude Stein from the American continent who tried to reject logos which fastened to Western theatre with a tight belt without negating text, while writing her first play What Happened. In experimental theatre attempts of the 1970s, the text was not totally rejected: in the experimental theatre from Robert Wilson to Richard Foreman or in the new-textuality from Sarah Kane to Martin Crimp, the density of the word and writing was altered; thus, a hybridization that exceeded both the theatre and performance classic definitions was revealed. The aim of this article is to exemplify the anti-narrative strategies of Gertrude Stein's plays, in which she tried to remove the "sequence-of-events" of the absolute condition of the conventional narrative definition instead of negating text.

Keywords: Gertrude Stein, Anti-Narrative, Landscape Text, Dramatic Structure, Postdramatic 


\section{EXTENDED ABSTRACT}

The 1970s theatre/performance opposition took its primary conceptual basis from the attempts to erase text from the theatre. Roland Barthes' well-known formula of theatricality was theatre-minus-text; and this formula went into the field of performance. Hans-Thies Lehmann argued that drama went beyond itself after the 1970s; thereby he derived the term of postdramatic. According to all these formulas, text seems to be excluded from theatre; but is the essence of the matter that simple?

To be able to grasp the ontological transformation of not only theatre but drama since the 1970s; it was necessary to evaluate carefully without falling into various academic clichés of the erosion of dramatic structure and of the new understanding of textuality. As a matter of fact, in experimental theatre attempts of the 1970s, text was not totally rejected: in the experimental theatre from Robert Wilson to Richard Foreman or in the new-textuality from Sarah Kane to Martin Crimp, the density of the word and writing was altered; thus, a hybridization that exceeded both the theatre and performance classic definitions was revealed.

The Historical Avant-garde period's first objection to text was at the centre of dramatic structure. But, if The Theater and its Double of Antonin Artaud's dated 1938 is carefully examined, it can be seen that all the anti-textual arguments were based on the logocentric structure of the theatre. In his work, Artaud explained that a Western individual who abstracts life through a system of thoughts was imprisoned in his/her mind and language. The word derived from the mind kills the magic of life, and civilized man was lost in a dead intellectual notion. Theatre derived from the western mind is shaped in a text axis due to its logocentric character and as such, it was doomed to be dead theatre without magic. Artaud wanted to enliven the Western theatre that had become an inanimate representation. Apparently, in order to be freed from the logocentric nature of Western theatre, erasing text from the theatre was the only solution for Artaud.

In this article, in contrast with Antonin Artaud from Continental Europe who objected to the "rational word" logos and therefore to text; Gertrude Stein from the American continent was examined because she tried to reject logos which fastened to Western theatre with a tight belt without negating text, while writing her first play What Happened. Instead of negating text, Stein tried to remove the "sequence-of-events" of the absolute condition of the conventional narrative definition. She was also important for being a direct reference to experimental theatre directors such as Robert Wilson, Heiner Goebbels, Judith Malina, and Richard Foreman.

Gertrude Stein, as a playwright, wrote without excluding language and text, yet she undermined the dramatic conventions of Western theatre explicitly. The anti-textuality of the Historical Avant-garde is undoubtedly an attitude towards a dramatic tradition that believed in 
the possibility of representation. Gertrude Stein completely ignored the representational basis of dramatic convention, shattered the narrative, disintegrated the dramatic convention's past tense oriented time order, and questioned the notion of composing a scene in the naturalist sense by proposing a concept of "landscape text". Therefore, it would be wrong to consider her plays from the category of closet drama and say that these plays do not suggest a new theatrical aesthetic. It was precisely for this reason that Gertrude Stein was an important figure for the new avant-garde theatre aesthetics after the 1970s, fed by the historical avant-garde. She reconsiders language notion without rejecting it, which was also a phenomenological question in her plays. The aim of this study, was to grasp the textuality understanding of postdramatic theatre. The study examined Gertrude Stein's anti-narrative strategies such as "the essence of what happened" exploratory, "landscape text" concept and phenomenological approach using examples from her plays. 


\section{Giriş}

1970'li yılların tiyatro/performans kutuplaş(tır)ması, öncelikli kavramsal dayanağını tiyatrodan metni silme girişimlerinden alır. Roland Barthes'ın ünlü teatrallik formülü tiyatroeksi-metin şeklindedir; geriye performans alanı kalır. Hans-Thies Lehmann, 1970'li yıllardan sonra dramın öte tarafına geçildiğini öne sürer ve postdramatik kavramını türetir. Tüm bu formüllere göre tiyatrodan metin dışlanmakta gibidir; fakat işin aslı böylesine basit midir?

Salt tiyatronun değil, dramanın 1970'li yıllarla birlikte geçirdiği ontolojik dönüşümü doğru bir biçimde kavrayabilmek için, dramatik yapıdaki çözülmelere ve yeni metinsellik anlayışına çeşitli akademik klişelere düşmeden, dikkatle yaklaşmak gerekiyor. Nitekim, 1970'li yılların deneysel tiyatro girişimleri, tiyatrodan metini topyekûn dışlamış değildir: Robert Wilson'dan Richard Foreman'a deneysel tiyatro ya da Sarah Kane'den Martin Crimp'e yeni metinsellik, sözün ve yazının özgül ağırlığını başkalaştırmış; böylece hem tiyatro hem de performans klasik tanımlarının dışına taşan bir melezlenme açığa çıkarmıştır.

1970’lerle birlikte, dramın öte tarafında, kesin olarak söylenebilecek ilk şey dramatik yapının artık eski işlevini yitirdiğidir. Metnin varlığı ya da yokluğu, konumu ve işlevi ise değişkendir. Dolayısıyla, bu eski işlevin ne olduğunu hatırlayarak başlamakta yarar var: Antik Yunan'dan geçtiğimiz yüzyıl dönümüne dek logosmerkezli ${ }^{1}$, mimetik temsil esasına dayalı, psikolojizmden temellenen ve sahnede yanılsamacı bir dünya kuran bir tiyatro tasavvuru söz konusuydu. Tarihsel Avangardlarla birlikte klasik temsil rejiminin sorunsallaşması, tiyatroda söz konusu bu saikler ekseninde şekillenen dramatik yapının çözülmesi anlamına gelecekti. Bu noktada dramatik yapının çözülmesini tiyatrodan metnin dışlanması olarak değil, logosmerkezli yapının işlevsizleşmesi şeklinde düşünmek, 1970 sonrasındaki tiyatroyu ve metnin başkalaşan değerini kavrayabilmek bakımından daha doğru görünüyor.

Öte yandan Tarihsel Avangard süreçteki ilk itirazlar, elbette dramatik yapının merkezinde yer alan metine yöneldi. Fakat Antonin Artaud'nun 1938 tarihli yapıtı Tiyatro ve İkizi2 dikkatle incelendiğinde, metin-karşıtı tüm argümanların esasında tiyatronun logosmerkezli yapısına yöneltilmiş olduğu görülür. Söz konusu yapıtında Artaud, yaşamı düşünceler dizgesi üzerinden soyutlayan Batılı insanın akıl ve dil yetisi içinde hapsolduğunu anlatmaktadır. Bu akıldan türeyen söz, yaşama has büyüyü öldürmekte ve uygar insan ölü bir düşünsel tasarım içinde yitip gitmektedir. Batı aklının benimsediği tiyatro, logosmerkezli karakterinden dolayı metin ekseninde şekillenmiştir ve bu haliyle büyüden yoksun ve ölü bir tiyatro olmaya mahkumdur.

1 Batı sanatına özgü klasik temsil anlayışı, Antik Yunan'dan geçtiğimiz yüzyıl dönümüne dek logos ekseninde yapılanmıştır. Batı tiyatrosu, metin-merkezli ve akılcı karakterini logostan almaktadır. 18. yüzyıldan 19. yüzyıla geçerken Batı düşününün dil ve anlam ilişkisini tartışmaya açması, Tarihsel Avangardların benzetmeci klasik temsil anlayışını reddetmesiyle sonuçlanır. Böylece tüm sanatlar kendi diline ve malzemesine itiraza koyulur; tiyatronun itirazı ise doğrudan dramatik metnin kendisine olacaktır.

2 Antonin Artaud, Tiyatro ve İkizi, çev. Bahadır Gülmez, (İstanbul: Yapı Kredi Yayınları, 1993). 
Dolayısıyla Artaud, Batı'da artık cansız bir temsil halini almış tiyatroya can katmak adına tek çözümü, tiyatrodan metni dışlamakta bulur.

Bu çalışmadaysa, Kıta Avrupası'nda “akılcı söz” logosa, bu yüzden de metine itiraz eden Antonin Artaud'nun aksine Amerika kitasında ilk oyunu What Happened'1 [Ne Oldu] yazarken Batı tiyatrosuna sımsıkı bir kemerle eklemlenmiş logosu, metini dışlamadan reddetmeyi deneyen Gertrude Stein'ın izini sürmeye çalışacağız. Metini dışlamak yerine konvansiyonel anlatı tanımının mutlak koşulu "olaylar dizgesi”ni tiyatrodan kaldırmayı deneyen Stein; Robert Wilson, Heiner Goebbels, Judith Malina ve Richard Foreman gibi deneysel tiyatro yönetmenlerinin doğrudan referans verdiği bir isim olması bakımından önem kazanıyor. Bu yazıda, postdramatik tiyatronun metinsellik anlayışını kavrayabilmek adına, Stein'in “olayların özü” soruşturmasını, "peyzaj metin” konseptini ve fenomenolojik yaklaşımını oyunlarından örnekler vererek inceleyeceğiz.

O halde, sorumuz şöyle: Tarihsel Avangardlardan günümüze, dilin anlamı karşılamadığ1 düşüncesinden hareketle doğan tüm karş1-temsil stratejilerini, ve eğer tiyatrodan söz ediyorsak, Tarihsel Avangardlarla birlikte iyice belirginleşen temsil esasına dayalı dramatik yapıdaki çözülmeleri, an-anlam-anlamak-anlatmak gibi sözcüklere de gebe "anlatı" kavramıyla beraber düşünmek ve Aristotelesçi anlatı tanımının dramatik yapı kavramıyla nasıl üst üste bindiğini saptamak bizi bir yere çıkarır mı? Sanıyorum yanıt, türettiği peyzaj metin kavramı ekseninde biçimlenen karşı-anlatı stratejileriyle çağdaş tiyatronun metinsellik kavrayışını bir asır öncesinden tarif etmeye uğraşan Gertrude Stein'in tiyatro anlayışında gizli.

\section{Anlatı ya da Dramatik Yapı}

Tiyatronun ne'liği üzerine bilinen ilk kuramsal çalışma Aristoteles' in Poetika's1. ${ }^{3}$ Salt tiyatro değil, plastik sanatlardan yazınsal sanatlara ve sinemaya dek neredeyse tüm bir Batı sanatı Aristoteles'in öne sürdüğü savlar ve karşıtlıklar ekseninde biçimleniyor. Bilindiği üzere, tüm sanatların taklit/ temsil esasına dayandığını söyleyen Aristoteles, mimesis kavramını sanatın olmazsa olmazı olarak en yukarıya yerleştiren isim. Aristotelesçi konvansiyon içindeki klasik anlayış, sanatın hakikati karşıladığı değil, temsil ettiği ve dolayısıyla özünün mimetik olduğu iddiası üzerine kurulu.

Sanatsal ifadeyi mimesis ve diegesis olmak üzere iki kipte ele alıyor düşünür, ilki olayların doğrudan, ikincisi dolaylı yolla aktarımı. Bu durumda mimesise, "konuşma ve eylemin doğrudan takdimi”ne dayalı sanatları (tiyatroyu) işaret eden bir alt tanım daha eklenmekte. Diegesis ise sözel ifadeye, olayların sözlü temsiline dayalı sanatlara denk düşüyor. Aristotelesçi konvansiyon içinde tiyatro, olayların doğrudan, sahne üzerinde ve eylem içindeki aktarımı olduğundan en mimetik tür. Diegetik küme ise yazın türüne tekabül eden, sözel ifadeye dayalı sanatlarla birlikte düşünülüyor; şiirle, destanla, ilerleyen zamanlardaysa öykü ve romanla.

3 Aristoteles, Poetika, çev. İsmail Tunalı, (İstanbul: Remzi Kitabevi, 1987). 
Pek çok sözlükte ve gündelik dilde anlatı [narrative] sözcüğünün tanımı başlangıçta çok açık: sözlü veya yazılı olarak bir dinleyene/izleyene/okuyana anlatılan olaylar dizgesi (öykü). Görünen o ki bu tanım diegesis kipi üzerinden dolayıma girmiş ve anlatı dendiğinde sanıyorum ilk etapta bu yüzden akıllara hikâye anlatıcılığı [storrytelling] geliyor. Öte yandan, konvansiyonel literatür anlatı tanımını "olaylar dizgesi” sözcügüüe odaklanarak yapmakta. En genel tanım şöyle: "bir olayın veya bir dizi olayın temsili"4. Dikkat edilirse hem mimesis hem de diegesis tanımlarında işaret edilen özne yine aynı: doğrudan ya da dolaylı, ama aktarılan "olaylar". Öyleyse, Aristotelesçi Batı sanatı anlatı tanımının merkezine "olay” unsurunu yerleştiriyor; anlatının klasik ve genelgeçer varlık koşulunu olay(lar dizgesi) olarak kabul ediyor.

Tiyatro içinden düşününce, "bir olayın veya bir dizi olayın temsili" şeklindeki klasik anlatı tanımının başka bir terimle aynı kapıya çıktığı görülmekte: tiyatroda "dramatik yapı" olarak kullanılagelen yaygın ifadeden söz ediyorum. Kavram, çoğunlukla Gustav Freytag'ın 1863 tarihli Freytag's Technique of Drama [Freytag'ın Dram Tekniği] çalışmasına referans verilerek kullanılıyor. ${ }^{5}$ Poetika esas alınarak formüle edilen dramatik yapı kavramıyla, yine olaylar dizgesi ve bu dizgenin neden-sonuç ilişkisi içindeki düzeni kastedilmekte. Burada tuhaf olansa Poetika'nın ne anlatı ne de dramatik yapı tanımlarını doğrudan içermiyor oluşu. İsmiyle müsemma, Poetika, temelde şiir sanatı üzerine:

Üzerinde konuşmak istediğimiz konu, şiir sanatıdır; ilkin genel olarak şiir sanatının ne olduğu, sonra şiir sanatının türleri ile bu türlerin teker teker ne oldukları, sonra da bir şiirin başarılı bir şiir olabilmesi için, onda konunun (öykü=mythos) ne şekilde işlenmesi gerektiği, $[\ldots]^{6}$

Fakat özelde üzerine eğildiği şiir türü tragedya. ${ }^{7}$ Görünen o ki, Aristoteles' in "tragedya nasıl olmalı" sorusuna verdiği yanıtlarla, "tutarlı ve bütünlüklü bir anlatı nasıl olmalı" ve "dramatik yapı nasıl olmalı" sorularını da yanıtlıyor Batı literatürü. Ve olay(lar dizgesi) yanıtı böylece bir tanıma dönüşüyor: hem anlatının hem de dramatik yapının tanımına. Sorumuz şu: bir eylem / hareket / olay olmaksızın anlatı mümkün müdür? Bu soru önemli, çünkü Gertrude Stein'in tasavvurundaki tiyatro tam olarak bu sorunun yanıtını arıyor. Anlatının ya da dramatik yapının göbeğinden olay unsurunu çektiğimizde konvansiyonel anlatının tersine çalışan bir yapıyla karşılaşacağız ve karşı-anlatı sözcüğü, bu noktada dramatik yapının iflasıyla üst üste binecek.

4 H. Porter Abbot, The Cambridge Introduction to Narrative, (New York: Cambridge University Press, 2008), s. 13.

5 Gustav Freytag, Freytag's Technique of Drama: an exposition of dramatic composition and art, çev. Elias MacEwan, (The Internet Archive: 2007), erişim 25 Ocak 2020, https://archive.org/details/freytagstechniqu00freyuoft/page/n3

6 Aristoteles, Poetika, s. 12.

7 Poetika'da şiir sanatına dâhil ettiği türleri şöyle sıralar Aristoteles: “epos, tragedya, komedya, dithrambos şiiri ile flüt, kitara sanatlarının büyük bir kısmı”. Aristoteles, Poetika, s. 12. Tüm bu sanatların ve sonrasında örneklediği görsel sanatların arasından tiyatroyu, diğer sanatlarca kullanılan tüm taklit araçlarını kullanması bakımından ayırır: "O halde birkaç sanat daha var ki, bunlar bütün bu adı geçen taklit araçlarını kullanırlar: Ritm'i, melodi'yi ve mısra ölçüsünü. Bu sanatlar, dithtrambos şiiri, nomen şiiri, tragedya ve komedya 'dır. Fakat bu sanatlar da kendi aralarında tekrar şu yönden birbirlerinden ayrılırlar: İlk ikisi; bu taklit araçlarını baştan sona dek kullanır; tragedya ve komedya ise onları yalnız belli bölümlerde kullanırlar. Bütün bunlar, sanatların kullandıkları taklit araçları yönünden gösterdiği ayrılıklardır.” Aristoteles, Poetika, s. 13. 


\section{Dramdan Peyzaja: Gertrude Stein}

\section{Dramın Senkopal Zamanından Sürekli Şimdiki Zamana}

Gertrude Stein, 1934 yılında çeşitli Amerikan üniversitelerinde verdiği Plays [Oyunlar] ${ }^{8}$ başlıklı konferanslarında What Happened [Ne Oldu] isimli ilk oyununun ortaya çıkış sürecinden söz eder. Söylediğine göre konvansiyonel bir oyun izlediğinde içini her seferinde bir sıkıntı kaplamaktadır. Bu sıkıntının sebebini bir seyirci olarak kendi duygusal zamanıyla oyunun duygusal zamanının asla örtüşmeyişi şeklinde açıklar Stein. ${ }^{9}$ Seyircinin zamanı ile oyunun zamanı farklı akmaktadır; çünkü konvansiyonel dramda şimdi her daim geçmişin gölgesinde şekillenir. Bu durumda sıkıntı "geçmişte bir şey olur, gölgesi bugüne düşer" ${ }^{10}$ formülünden kaynaklanmaktadır ve Stein bu sıkıntıyı senkopal uyumsuzluk olarak tarif eder. Charles Bernstein'in sözleriyle,

Dramatik tiyatro çoğunlukla A'dan B'ye, B'den C'ye hareket ettiğimiz fikri üzerine kuruludur ve ilerleyebilmek için nereden başladiğımızı hatırlamak zorundayızdır. Bu durumda asla şimdiki zamanda olamaz ve (Stein'in) senkopasyon dediği yerde tıkalı kalırız. ${ }^{.1}$

Gertrude Stein senkopasyon [syncopation] sözcüğünü zamansal uyumsuzluk/aksama anlamlarında kullanmaktadır. Senkop [synkópē] sözcüğü Eski Yunan'da kesinti, (birbirine vurarak) kırılma anlamına gelmektedir. Günümüz itibariyle sözcük dilbilim, tıp ve müzik alanlarında dolayım kazanmıştır ve "gramerde bir ses veya hecenin yutulması, tıpta kısa süreli bilinç kaybı, müzikte aksak ritm"12 anlamlarında kullanılmaktadır. Senkopasyon ifadesi ile Stein tiyatro sahnesinde "görülen" ile görülenin seyirciye "hissettirdiklerinin" aynı tempoda yürümediğine dikkat çekmektedir. Stein’e göre, her şeyden önce sahnede seyirciye kendi temposuyla perde arkasının temposunun aynı olmayacağını daha en baştan hatırlatan bir perde vardır. Perdenin diğer tarafında kalan olarak seyirciye geçen his, perdenin ötesindekiyle aynı anda ilerleyemeyeceğidir. Bir taraf daima diğer tarafın arkasında veya önünde olacaktır. ${ }^{13} \mathrm{Bu}$ durumda perdenin önü ve arkası varsayımsal olarak farklı fiziksel yasaların işlediği iki ayrı evrendir ve oyun evrenindekiler ile seyirci evrenindekiler aynı zaman ve mekâna gömülü değildir.

Stein, Plays [Oyunlar] başlıklı konferanslarında öne sürdüğü senkopasyon sıkıntısını daha iyi açıklayabilmek için gerçek yaşam, öykü ve tiyatro sahnesi arasında heyecan duygusu ve

8 Gertrude Stein, "Plays", Look at Me Now and Here I Am: Writings and Lectures 1909-45 içinde, (London: Penguin Books, 1990), s. 59-83.

9 Leslie Atkins Durham'dan aktaran: Ferdi Çetin, ““Continuous Present” in Gertrude Stein's Plays”, (Yüksek Lisans tezi, İstanbul Üniversitesi, 2013), s. 4.

10 Batı dramatik yazınında "geçmişin şimdiyi şekillendirmesi” formülüne dair kapsamlı bir çalışma için bkz. Beliz Güçbilmez, Zaman / Zemin / Zuhûr: Gerçekçi Türk Tiyatrosunda Minyatür Kurgusu, (Ankara: Deniz Kitabevi, 2006), s. 22-59.

11 Charles Bernstein'den aktaran: Arnold Aronson, American Avant-Garde Theatre: A History, (New York: Routledge, 2007), s. 53.

12 Sevan Nişanyan, "Senkop”, Nişanyan Sözlük: Çă̆daş Türkçenin Etimolojisi, 2012-2017, Erişim 26 Mart 2018 http://www.nisanyansozluk.com/?k=senkop

13 Gertrude Stein, "Plays", s. 60. 
zaman kullanımı üzerinden karşılaştırmalar yapar. Stein'a göre, gerçek yaşamda heyecan verici bir olaya dâhil olan kişi ile sahnedeki teatral heyecanı takip eden kişinin hissiyatı aynı değildir. Her ikisinde de olay en sonunda bir nihayete erer; fakat gerçek yaşamda heyecan duygusu sadece sonlanırken, tiyatroda olan heyecandan kurtularak rahatlamaktır ve Stein için bu ikisi birbirinden hissiyat olarak çok farklıdır. Adam Frank'a göre, Stein bu sözleriyle tiyatrodaki heyecanın basitçe sonlanmadığını, doruğa çıkarak neticelendiğini anlatmaktadır ve bu durum Aristotelesçi katharsis geleneği ile ilgilidir. ${ }^{14}$ Başka bir deyişle, Stein tiyatrodaki heyecanın "acıma ve korku duygularını uyandırarak ruhun tutkularından arındırılması"15 ödevine çıktığına işaret etmektedir; gerçek yaşamdaysa heyecan duygusu yalnızca sonlanır. O hâlde Stein'a göre dramatik metinlerde kullanılan zamansal dizge katharsisi sağlayacak şekilde düzenlenmekte ve bu yoğun tempo seyirciye gerginlik olarak yansımaktadır.

Bir diğer örneğini öykülerden veren Stein, bir kitap okurken kişinin zamanı kendisinin kontrol edebildiğine, fakat tiyatroda bunun asla mümkün olmadığına dikkat çeker. Stein'a göre her şeyden önce kişi kitap okurken heyecanını ve merak duygusunu yatıştırmak için dilerse kitabın son sayfalarını açıp okuyabilir. ${ }^{16} \mathrm{O}$ hâlde öykünün zamansal dizgesi kişiyi doğrudan bağlamaz: okur anlatının zamanına bu anlamda hükmedebilir ve verili zamansal dizgeye uymayarak zamanı kendi kontrolüne almış olur.

Tüm bunların yanı sıra, Stein'a göre, konvansiyonel tiyatrodaki sıkıntıyı doğuran başka bir durum aşinalık [familiarity] problemidir. Aynı sorun edebiyat okuru için de geçerlidir, fakat tiyatroda bu sorunu aşmak daha problemlidir. Şöyle söyler Stein:

Kişi bir oyun okuduğunda ve çoğu zaman kişi bir oyun okurken, ya da diyelim ki kişi bir Shakespeare oyunu okuduğunda, en olmadı çoğu zaman ben okurken, en azından tüm bir ilk perde boyunca kişinin parmağını karakterler listesinin olduğu sayfada tutması her daim bir zorunluluk ve oyun izlerken de bir şekilde aynı gereksinim doğuyor. ${ }^{17}$

Tiyatroda karakterlere aşinalık kazanmak Stein'a göre mümkün değildir çünkü oyuncular seyircinin hemen yanı başında, sahnededirler, ${ }^{18}$ dolayısıyla kimin kim olduğunu çözmek ve oyunu takip edebilmek için seyirci zamanla yarışmak zorunda kalır. O hâlde bu bir sahnesel mevcudiyet [presence] sorunudur ve sahne üzerindeki oyuncuyu anlatının içinde geçmişe gömmek yerine şimdi ve burada tutmak gerekmektedir.

14 Adam Frank, "Loose Coordinations: Theater and Thinking in Gertrude Stein", Science in Context 25 (3), (2012), s. 454.

15 Aristoteles Poetika'da katharsis kavramını böyle tanımlar: "Tragedyanın görevi, uyandırdı̆̆ı acıma ve korku duygularıyla ruhun tutkulardan arınmasını sağlamaktır.” Bkz. Aristoteles, Poetika, s. 22.

16 Gertrude Stein, "Plays", s. 63.

17 a.e., s. 69.

18 a.e. 
Böylelikle Stein, konvansiyonel drama özgü bir sorun olarak düşündüğü senkopal uyumsuzluğu çözmek için, her şeyin şimdiki zamanda geçtiği bir tiyatro tasavvur eder. ${ }^{19}$ Ferdi Çetin'in “Continuous Present” in Gertrude Stein 's Plays [Gertrude Stein'ın Oyunlarında "Sürekli Şimdiki Zaman”] başlıklı yüksek lisans tezinde ifade ettiği gibi, neler olup bittiğini bir hikâye anlatmadan aktarmak, neden-sonuç ilişkisine dayanarak hikâye anlatma üzerine kurulu geleneksel kanona karşı çıkmak anlamına gelmektedir. Stein'e göre her zaman ve her şekilde bir şeyler olup bitmektedir; o hâlde hikâyeyi başlangıcı ve sonu olacak şekilde kurmak aslında bir gereklilik değildir. Bu sebeple Stein, seyircinin alışkın olduğu tiyatrodan tamamen farklı olarak, oyunlarının zamanını şimdide tutmayı ve "ne oldu?" sorusuna şimdide olup biten her şeyi, yani şimdiki zamanın tüm dinamiklerini anlatarak cevap vermeyi seçer. ${ }^{20}$ Tekrar tekrar aynı ana dönmek ve "tekrar tekrar yeniden başlamak", Stein'in şimdide kalmak için türettiği yöntemlerin ilkidir. Böylece seyirciye "hiçbir önbilgi ve hiçbir beklenti" ${ }^{21}$ sunmaksızın, şimdiki zaman sürekli kılınmış olur.

\section{Olayların Özü: Ne Oldu}

Zaman bir çizgi değil, bir yönelimsellikler ă̆ı dır. -Maurice Merleau-Ponty, Algının Fenomenolojisi

Gertrude Stein için “ne oldu?” sorusu salt geçmişi ilgilendiren bir konu olmadığından, oluş edimini zamandan bertaraf ele almak gerekir. Zaman ve olay kavramlarını alışılageldik sınırların dışında düşünmeye çalışan Stein, anlatı kavramını tanımı gereği geçersiz kılmış olur. Anlatı, en genel tanımıyla, "bir olayın veya bir dizi olayın temsili”" şeklinde düşünülmektedir. ${ }^{22}$ H. Porter Abbott'a göre burada anahtar sözcük “olay”dır. Ortada bir olay (ya da olaya tekabül eden bir kavram olarak eylem) olmadığında, elinizde belki bir tanım, yorum, iddia, lirik veya bunların bir tür bileşimi olabilir, ancak bu durumda elinizdeki bir "anlatı" değildir. ${ }^{23}$ Benzer bir şekilde, Robert Scholes şöyle söyler:

Kişi bir resmi, bir kişiyi ya da bir binayı, bir ă̆acı ya da bir felsefeyi anlatamaz. Anlatı, nesnesini kendi anlamına dâhil eden bir kelimedir. Yalnızca bir tür şey anlatılabilir: bir zaman-olayı, ya da normalde kullandığımız sözcükle ifade edersek, bir "olay” [event]. Daha doğrudan söylersek, bir anlatının varlığından söz edebilmemiz için birden fazla olaya ihtiyaç vardır. Peki, olay nedir? Gerçek bir olay, meydana gelen bir şeydir: bir vaka, bir hâdise, bir etkinlik. ${ }^{24}$

19 Leslie Atkins Durham'dan aktaran: Ferdi Çetin, a.e., s. 4.

20 a.e.

21 Charles Bernstein'den aktaran: Arnold Aronson, American Avant-Garde Theatre: A History, s. 53.

22 H. Porter Abbot, The Cambridge Introduction to Narrative, s. 13.

23 a.e., s. 13.

24 Robert Scholes, "Language, Narrative, and Anti-Narrative", Critical Inquiry, 7, (1980), s. 209. 
O hâlde Stein, olay ve zaman kavramlarını sorgulamakta ve anlatı kavramının en temel iki bileşenini tartışmaya açmaktadır. Yazar, 1913 tarihli ilk oyunu What Happened'ta [Ne Oldu], adından da anlaşılabileceği üzere tamamıyla bu sorun üzerine yoğunlaşır. Söylediğine göre bu oyunu yazmaktaki amacı “olayların özü”nü ele almaktır ${ }^{25}$ ve Stein'e göre olayların özü yaşamın doğal akışı içinde her an olmakta olan her şeyle ilişkilidir:

Her zaman bir şey oluyor, insanların hayatlarıly ilgili hikâyeleri bilen herkes bilir ki her zaman bir şeyler olur, her zaman bir dolu gazete vardır ve her zaman ylğılnla özel hayat. Herkes bir sürü hikâye bilirken başka bir hikâye anlatmanın ne anlamı var? Etrafta bu kadar hikâye varsa ve herkes bir dolu hikâye biliyor ve anlatıyorsa hikâye anlatmanın amacı nedir? Ülkede her daim olağanüstü derecede karmaşık pek çok drama yaşanıyorken. Ve herkes bunları biliyor, bir tane daha anlatmanin gereği ne? Her zaman devam eden bir hikâye vardir. Hâliyle bu yüzden oyunumda herkesin bilmediği ve her zaman anlatmadiğtyla ilgilenmek istedim. ${ }^{26}$

Oyun, geleneksel anlamda bir olay ve/veya olaylar dizisi içermez. Keyifli ve kalabalık bir akşam yemeği sonrası eve döndügünde bu oyunu yazdığını söyleyen Stein, ${ }^{27}$ akşam yemeği olayını hikâye etmez, daha ziyade betimler. Fakat söz konusu betimlemede klasik anlatılara özgü üçüncü tekil şahıs ve geçmiş zaman kullanımı yoktur; “akşam yemeği olayı” anlatılmaz, "akşam yemeği fenomeni” aktarılır:

\section{PERDE}

(ÜÇ.)

Dört ve kimse yarasız, beş ve kimse dört başı mamur, altı ve kimse konuşkan, sekiz ve kimse duyarl.

Bir ve çok ağır bir sol kanat kaldırışı ki mükemmel şekilde söylemenin hiçbir yolu yok.

Bir kesinlik noktasl, tuhaf bir ocak noktast, çok dengeli bir nokta o kadar ki geriye kalan sebep yükselme şansı.

(Aynı Üç.)

Bir geniş meşe yeterince geniş meşe, çok geniş bir pasta, hafifletici bir kurabiye, genişçe bir aralık ve parlayan aynı çuvalla doldurulmuş el değiştirmiş bir kutu.

En iyi daha iyi tek ve dahast sol ayakl bir yabanci.

Incelik bütün limonlarda portakallarda elmalarda armutlarda ve patateslerde var. (Aynı $\ddot{U} c ̧$ )

Aynısı bir çerçeve daha üzgün bir giriş kapısı, tekil bir kapı ve parantez içine alınmış bir kaza. Her yerde olduğundan daha fazla ayın hatıralarının olduğu zengin bir pazar ve tuhaf bir şekilde klyafetlerin ve bütün bir topluluğun olduğu yer.

Bir bağlantı, bir istiridye kabuğu bağlantısı, bir anket, bir bilet ve araya dönüş. ${ }^{28}$

25 Gertrude Stein, "Plays", s. 75.

26 a.e.

27 a.e.

28 Gertrude Stein, Ne Oldu, çev. Ferdi Çetin, yayınlanmamış çeviri. 
Stein, akşam yemeğini kendi çevreselliği içinde aktarır ve olaylara odaklanmaz; dolayısıyla daha ziyade "akşam yemeği fenomeni” ile ilgilenir. "Fenomen" kavramını burada, çok basitçe, (herhangi türde) bir bilinç tarafindan algılanan, bilinçte beliren (yine herhangi türden) bir varlık olarak kullanıyorum: akşam yemeğinin bilinçteki izdüşümü, algısallıkla birlikte bilinçte şekillenen görüngü. Söz konusu görüngü ancak öznenin algıladığı kadarıyla ve kavradığı şekliyle, dolayısıyla kişinin bilincinde var olmaktadır.

Stein'ın olaylarla değil “olayların özü” ile ilgilendiğini söyledik. Yazar, anlatının olmazsa olmazı sayabileceğimiz olay ve zaman kavramlarını, söz konusu özü açığa çıkarabilmek için paranteze almaktadır. Paranteze alma yöntemi ile Husserl fenomenolojisinin önerdiği fenomenolojik indirgeme yöntemi arasında belirgin paralellikler kurulabilir. Dahası, Stein'in fenomenolojik indirgemeyi tiyatro alanına taşıdığı ve tiyatroya özgü doğal tavrın karşısına yerleştirdiği söylenebilir. Fenomenolojik indirgeme, "doğal davranışın bırakılması ve farklı bir bilinç durumuna geçilmesi gerektiğini öne sürer.” Husserl, bu tavrı paranteze alma [epoché] "olarak adlandırır ve doğal davranışın karşısına koyar.” 29

Fenomenolojik paranteze almanın en önemli amacı felsefi düşünme ve felsefi sorgulamada önceden "doğal tavir-alma" yı engellemek, bu doğrultuda oluşabilecek herhangi bir "genel tez" $i$ yürürlükten kaldırmaktır. Başka bir deyişle paranteze almadaki amaç fenomenolojik indirgemede olduğu gibi dünyanın özünü onu rastlantısal dı̧̧ görünüşlerinden soyarak ortaya çıkarmaktır. Böylelikle doğal dünyanın kendisinin paranteze alınmasıyla fenomenolojik indirgemenin doğal tavrından çıkılarak saf bilinç elde edilmiş olunur. ${ }^{30}$

Stein, tiyatroya özgü “doğal tavrın” dışına çıkmakta ve "ne oldu?” sorusuna kişinin algısal farkındalığını uyandırarak tersten cevap vermektedir. Stein için bu sorunun cevabı olayların alışılageldik akışında değil olayların özündedir ve dolayısıyla amaç olayların "özünü onu rastlantısal dış görünüşlerinden soyarak" açığa çıkarmak olmalıdır.

Böylelikle izleyici, tiyatronun doğal zamanı ve doğal olay akışının dışında kalarak farklı bir bilinç durumuna geçer. Söz konusu farklılık, Stein'in kendine özgü tekrarları ve dil kullanımıyla seyirciyi şimdiki zamana odaklamak ve duysal algılarını açmak üzerinden işler.

Maurice Merleau-Ponty, "zamanı şimdilerin ardışıklığı olarak tanımlama hatasını 'bilinç içinde' tekrarladığımız müddetçe, onu şeylerden kendimize taşımakla bir şey kazanmış” olamayacağımızı söyler. ${ }^{31}$ Düşünüre göre "önceye ve sonraya göre mümkün olan bağıntılar dizisi”, yani kurgulanmış zaman, zamanın kendisi değildir ve mekâna aittir. Bu durumda

29 Cem Çınar, "Film Estetiğinde Gerçekçi Sinemanın Fenomenolojisi”, Doktora tezi, (İstanbul Üniversitesi, 2014 ), s. 24.

30 Hüseyin Aydoğdu, "Maurice Merleau-Ponty’nin Fenomenolojik Ontolojisi”, Doktora tezi, (Atatürk Üniversitesi, 2010), s. 86.

31 Maurice Merleau-Ponty, Algının Fenomenolojisi, çev. E. Sarıkartal \& E. Hacımuratoğlu (İstanbul: İthaki Yayınları, 2017), s. 552. 
kurgulanmış zaman özneden ayrı, "hareketsiz ve hiçbir şeyin olup bitmediği bir ortamdır."32 “Zamanı özne olarak, özneyi de zaman olarak anlamak"33 gerektiğini söyleyen düşünüre göre,

Şimdimin "içinde", onu hâlâ yaşayan şimdi olarak ve gerektirdiği her şeyle birlikte yeniden yakalayabilirsem, geleceğe doğru ve geçmişe doğru bir ekstaz olur ve bu, zamanın boyutlarının birbirine rakip olarak değil birbirinden ayrllmaz olarak görülmesini sağlar: Şimdide olmak, oldum olası olmak ve sonsuza dek olmaktır. Öznellik zamanın içinde değildir çünkü zamanı üstlenir veya yaşar ve bir yaşamın ilinti bütünlüğü ile karışıp bir olur. ${ }^{34}$

Algının Fenomenolojisi'nde Maurice Merleau-Ponty'nin zamana dair bu söylediklerinden hareketle, Stein'in "ş̧imdiki zaman"1 neden böylesine önemsediği üzerine akıl yürütmek mümkün görünüyor. Çünkü bu durumda “ne oldu?" sorusunu doğru bir biçimde yanıtlayabilmek için kurgulanmış zamanın dışına çıkarak, onu paranteze alarak düşünebilmek zorunluluğu doğar. Şayet kurgulanmış zaman esasında "hareketsiz ve hiçbir şeyin olup bitmediği bir ortam" ise, "ne oldu?" sorusunu yanıtlayabilmek ancak şimdiki zaman içinde kalıp "onu hâlâ yaşayan şimdi olarak ve gerektirdiği her şeyle birlikte yeniden yakalayabilmek" ile mümkün olacaktır. Dana Cairns Watson'un da söylediği gibi, Stein “olayların özü” derken aynı zamanda eyleme de vurgu yapmaktadır: zira bu kullanımda "öz” sözcüğüyle var olan şeyin içkin doğasına işaret edilmekte, fakat “olaylar" sözcügüüle etkinlik imâ edilmektedir. ${ }^{35}$ Etkinlik ise doğası gereği kurgulanmış zamana değil, sürekli şimdiki zamana aittir.

Stein'in seyirciyi “şimdide” tutabilmek için sürekli tekrarlara dayalı bir yöntem geliştirdiğini söyledik. Stein, örneğin bir sahne boyunca aynı cümleye tekrar tekrar başlayarak kişinin dikkatini sürekli olarak aynı ana, öte yandan dile yöneltmiş olur:

\section{PERDE}

(Ikki.)

Bir kesik, bir kesik bir dilim değildir, bir kesiği ve bir dilimi temsil etmenin ne âlemi var. Bütün bunların ne âlemi var.

Bir kesik bir dilimdir, bir kesik aynı dilimdir. Bir kesiğin bir dilim olmasının sebebi hiçbir telâşın olmaması ve zamanın yararlı olmasıdır.

(Dört.)

Bir kesik ve bir dilim bir kesikle bir dilim aynı olduğu zaman başka bir soru var mıdır.

Bir kesiğin ve bir dilimin hiçbir özel alıșverişi yoktur, farkl olan her şeye tuhaf bir istisnast vardır. Bir kesik ve tek bir dilim, tek bir kesik ve tek bir dilim, bir tattan geriye kalanlar kalabilirler ve tatma eksiksizdir.

Bir kesik ve bir olay, bir dilim ve bir vekil yalnız bir telaş ve bunu gösteren bir durum, bütün bunlar çok mantıklıdır her şey net olduğu zaman. ${ }^{36}$

32 a.e., s. 556

33 a.e., s. 566

34 a.e., s. 567.

35 Dana Cairns Watson, Gertrude Stein and the Essence of What Happens. (United States of America: Vanderbilt University Press, 2005), s. 66.

36 Stein, Ne Oldu. 
Stein, söz konusu tekrarlarla salt "sürekli şimdiki zaman” koşulunu sağlamaz, aynı zamanda kişinin dil mefhumuna odaklanmasını sağlar; zira kişi dünyayı ancak dil yoluyla kavrayabilmektedir. Ferdi Çetin'in de söylediği gibi, seyircinin dikkati bu tekrarlarla dil yoluyla kavranılan dünyaya (diğer bir deyişle olaylara) değil dilin kendisine yönelmektedir. ${ }^{37}$

Oyun, tek bir kişinin konuşmasıyla açılır, fakat ilerleyen bölümlerde konuşan kişi sayısı, tıpkı bir koro mantığıyla ikiye, üçe, dörde ve bazen beşe çıkar. Yukarıdaki örnekte de görülebileceği gibi kimi paragrafların giriş kısımlarında parantez içinde verilen sayılar, konuşan kişi sayısını belirtmektedir. Çetin'in de ifade ettiği gibi Stein, sahnedeki kişilerin kim olduğu ya da tam olarak neden bahsettikleri hakkında bilgi vermez. Ağızdan çıkacakların hiçbiri herhangi bir karakter için özel olarak yazılmamıştır: sahne üzerindekiler sırayla veya hep bir ağızdan konuşabilirler; ${ }^{38}$ aralarında müzikal bir uyum veya aksine bir kakafoni oluşabilir; ve metin, sahnelemeye dair bu anlamda herhangi bir öneri içermez. Böylelikle Stein, drama özgü konvansiyonun bir diğer olmazsa olmazlarından "diyalog" ve "karakter" öğelerini de ortadan kaldırmış olur. Konvansiyonel dramatik metinlerin aksine Stein oyunlarında etkinlik gösteren tek şey, dilin kendisidir ve bu etkinlik ancak şimdide mevcudiyet bulur.

\section{Dramın Mekânından Metinsel Peyzaja}

Gertrude Stein, “peyzaj olarak oyun” düşüncesini yazlarını Bilignin'deki (Fransa) kır evinde geçirmeye başladıktan sonra şekillendirir. ${ }^{39} \mathrm{O}$ vakte dek yazdığ 1 tüm oyunları Geography and Plays [Coğrafya ve Oyunlar] başlığı altında yayınlatan Stein, burada "her şeyin, hatta bir parça reklamın veya mektubun bile bir oyun olabileceği" sonucuna varır. ${ }^{40} \mathrm{Bu}$ sözleriyle konvansiyonel tiyatronun oyun tanımının "bir dizi olay"la başlamasına ve kendi tiyatrosunda olay örgüsünün yerinin olmayışına dikkat çekmektedir Stein. Her şey bir oyun olabilir, oyun olmaklığın ön koşulu "bir dizi olay”, dolayısıyla "anlatı" değildir. "Bir oyun yazmaya niyet etmek ve bunu beyân etmek"41 Stein için yeterlidir. Bilignin'deki doğa manzarası Stein’e peyzajın da başlı başına bir "şey” olduğunu düşündürür: "Kısacası fark ettim ki peyzaj bir şeydir, oyun da bir şeydir"42 diye yazar:

Şayet bir oyun tıpatıp bir peyzaj gibiyse o hâlde önünden veya arkasından oyuna bakan kişinin duygularına dair hiçbir güçlük yaşamayacağını fark ettim, zira peyzaj bir aşinalık yaratmak zorunda değildir. Peyzaja aşina olmak zorunda olabilirsin fakat peyzaj seninle değildir, yalnızca oradadır, bu durumda yazılı olan oyunla arandaki ilişki her zaman öylesine nettir ki ona bakmadığın sürece bu ilişkinin hiçbir önemi yoktur. ${ }^{43}$

37 Çetin, ““Continuous Present” in Gertrude Stein's Plays”, s. 22.

38 a.e., s. 20.

39 Stein, "Plays", s. 77.

40 Stein'den aktaran: Çetin, ““'Continuous Present” in Gertrude Stein’s Plays”, s. 26.

41 Stein, "Plays", s. 74.

42 a.e., s. 77.

43 a.e., s. 77. 
Bir oyunun aynı zamanda bir manzara/peyzaj gibi düşünülebileceği savını, oyunların roman veya öykülerden farklı olarak "izlenilebilir" nitelikte olmasıyla destekleyen Stein, "bakmak" ve "görmek" eylemlerini yapıtlarında sorunsallaştıran bir oyun yazarı olarak şöyle söyler: "Oyunlar bakınca görülebilen şeylerdir. Kimse görmeden olup bitenler diğer şeylerdir, bu yüzden romanlar oyun değildir." 44 Yazarın oyun ve peyzaj arasında kurduğu bu analojinin temelinde elbette bir sanat koleksiyoncusu olması ve dolayısıyla görsel sanatlara olan ilgisi bulunmaktadır. Isabelle Alfandary'e göreyse Stein' in peyzaj analojisi öte yandan bir “şimdi ve buradalık" [presence] metaforudur ve yazar "kişinin paylaşılamayan ve açıklanamayan duyularının saf varlığına" işaret etmektedir. Alfandary’e göre, "Bilignin manzarasından bütünüyle bir oyun oluşmaktaydı" diye yazan Stein için doğanın sanatı taklit etmesi sürpriz değildir, çünkü yalnızca anlamın ve mimetik işleyişin yönü tersine çevrilmiştir: Stein örneğinde sanat doğayı değil, doğa sanatı taklit etmektedir.45

Gertrude Stein'in anlatı kavramına yaklaşımı ile peyzaj/oyun ilişkisi üzerine düşüncelerinin gelişim noktasında bir ortaklık bulunmaktadır. Anlatıya hareket katan olaylar dizgesidir, fakat Stein'e göre hareket -yani olaylar dizgesi- olmadan da bir anlatı kurulabilir. Peyzaj ise hareketsizdir, fakat devinimini içindeki her bir öğenin bir diğeriyle ilişki hâlinde oluşundan alır. Bu durumda Stein'in olaylar dizgesinden yoksun anlatısı, hareketsiz olmasına rağmen ilişkisellikten doğan bir devinime sahip olan peyzaja benzemektedir. Tıpkı oyunun bir düzeninin olması gibi peyzajın da kendi içinde bir düzeni olduğunu söylen Stein, bu düzenek içinde her bir şeyin bir diğeriyle ilişki hâlinde oluşuna dikkat çeker: ${ }^{46}$

[...] peyzaj hareket etmez fakat her zaman ilişki içindedir, ağaçlar tepelerle, tepeler çayırlarla, ăgaçlar birbirleriyle, her bir parça bir diğeriyle ve gökyüzüyle ve her bir detay tüm diğer detaylarla. İster bir hikâye anlatmak ister dinlemek isteyin, hikâyenin önemi her hâlükârda orada bulunan bu ilişkidedir, ilişki de zaten oradadır. Işste bu ilişkiden bir oyun yapmak istedim ve yaptım, çok sayıda oyun yazdım. ${ }^{47}$

Öte yandan Stein, geliştirdiği peyzaj dramaturjisiyle dramın zamanına özgü senkopal sıkıntının artık bir sorun olmaktan çıktığı inancındadır. Erken dönem oyunlarında dile ve tekrarlara odaklanıp anlatısını şimdiki zamanda kurarak çözmeye çalıştığı bu sorun, oyunun bir peyzaj şeklinde düzenlenmesiyle ortadan kalkmaktadır. ${ }^{48}$ Şayet peyzaja özgü düzen birbirinden bağımsı gibi duran canlı ve cansız tüm bileşenlerin ilişkiselliğinden oluşmaktaysa, Wilford Leach'ın da ifade ettiği üzere, söz konusu bu bileşenlerin ne olduğu ya da nasıl bir değişim içerisinde oldukları fark etmez, zira oyun tam da zamanın ilişkisellikten doğan bu düzeni

44 Gertrude Stein, Everybody's Autobiography, (New York: Vintage Books, 1973), s. 195-196.

45 Isabelle Alfandary, "Page-Landscapes in the Theater of Gertrude Stein", Reflective Landscapes of the Anglophone Countries içinde, ed. Pascale Guibert, (Amsterdam-New York: Rodopi, 2011), s. 263-264.

46 Gertrude Stein, Look at Me Now and Here I Am: Writings and Lectures 1909-45, s. 78.

47 a.e.

48 Çetin, ““'Continuous Present” in Gertrude Stein's Plays”, s. 26. 
yansıtmasından oluşmaktadır. ${ }^{49}$ Tersten söylenecek olursa, tüm bu ilişkiselliğe haiz zaman, mekânın kendisi olarak, yani peyzaj olarak mevcudiyet kazanır. Bu durumda peyzaj dramaturjisi zamanı ve mekânı birbirinden bağımsız iki ayrı boyut olarak ele almaz, zaman ve mekân ilişkisini birbiriyle iç içe kabul ederek üst üste bindirir: peyzaj hem zamandır hem uzam.

\subsection{Four Saints in Three Acts}

Kendi kendimizle şüphe götürmez şekilde iletişim kurmamı, dünyayla iletişim kurarak olur. Zamanı bütün olarak elimizde tutarız ve kendi kendimize şimdi mevcut oluruz çünkü dünyada şimdi mevcuduzdur.

-Maurice Merleau-Ponty, Algının Fenomenolojisi

Gertrude Stein'in peyzaj dramaturjisini en iyi yansıtan oyunlarından biri olan Four Saints in Three Acts [Üç Perdede Dört Aziz] ${ }^{50}$, yazarın sahnelenen ilk metni olarak ayrı bir öneme sahiptir. Müziklerini Virgil Thomson'ın yaptı̆̆ı ve opera olarak sahnelenen oyun, prömiyerini 1934 yılında Brodway’de yapar. Sarah Bay-Cheng, söz konusu metin opera için yazıldığından “drama kategorisine tam anlamıyla dâhil edilebilir mi?" sorusuna verilecek yanıtların tartışmaya açık olduğunu; fakat Stein'in dramatik yazınının gelişimi içerisinde bu metnin "sahne metni”" konseptine bir giriş olarak öne çıktığını söyler. ${ }^{51}$ Oyun alışılageldik bir operadan beklenilenin aksine bir anlatı etrafında şekillenmez. Metin, sahne yönergeleri ve karakter listesine varıncaya dek opera için yazılmış standart bir oyunun sahip olması gereken her şeyi içermektedir; fakat bu içeriğe öykü dâhil değildir. ${ }^{52}$ Oyunda adı geçen azizler ve azizeler birer "oyun kişisi”" gibi ele alınmazlar. "Tarihsel arka plandan yoksun" ${ }^{33}$ k1lınan karakterler oyuna hizmet eden birer sahne eşyası [prop] olarak sunulur ve ancak peyzajın/manzaranın bir parçası olarak varlık gösterirler.

49 Wilford Leach, "Gertrude Stein and Modern Theatre", Doktora tezi, (University of Illinois, 1954), s. 145.

50 Gertrude Stein, "Four Saints in Three Acts", Operas \& Plays içinde, (New York: Station Hill Press, 1987), s. 11-47.

51 Sarah Bay-Cheng, Mama Dada: Gertrude Stein's Avant-Garde Theater, Mama Dada: Gertrude Stein's AvantGarde Theater, (New York \& London: Taylor \& Francis e-Library, 2005), s. 54.

52 Çetin, ““Continuous Present” in Gertrude Stein's Plays”, s. 31.

53 a.e., s. 33 . 


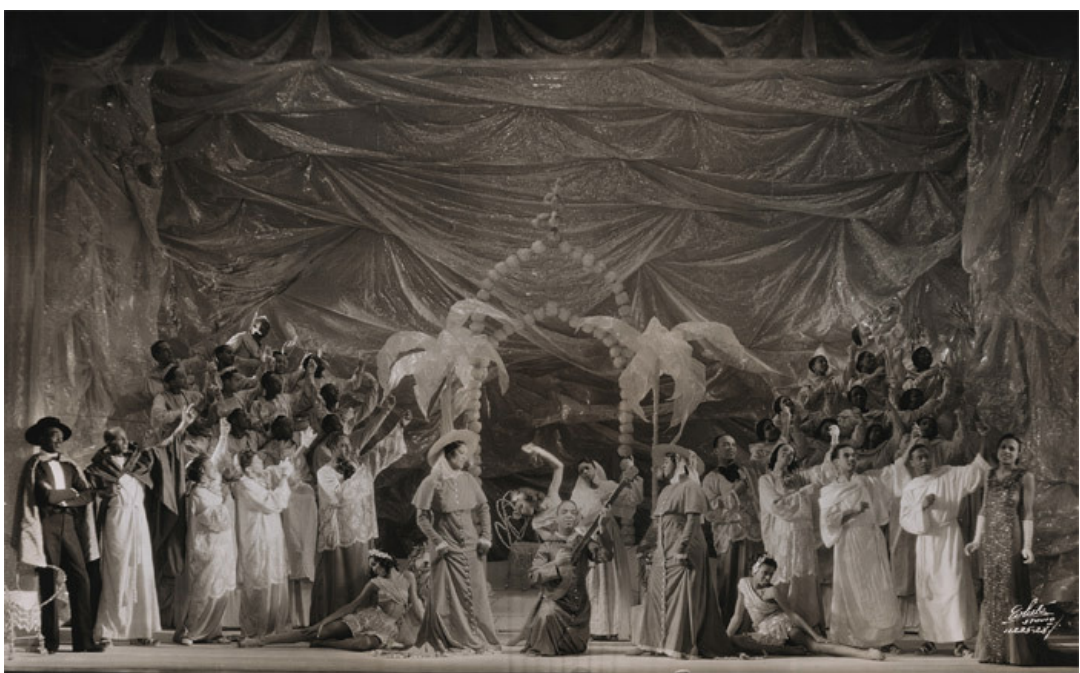

Four Saints in Three Acts, Yönetmen: John Houseman, Wadsworth Atheneum, Hartford, 1934. Fotoğraf: Harold Swahn.

Özellikle bu yönüyle ele alındığında Stein'in peyzaj metin kavramı 1970'lerle birlikte şekillenen, sahnelemeye hizmet eden her bir öğenin birbiriyle eşit değerde tutulduğu "sahne metni” konseptine büyük ölçüde referans olmuştur. Amerikalı tiyatro yönetmeni Robert Wilson'ın 1996 yılındaki ses getiren Four Saints in Three Acts sahnelemesi, peyzaj metin konseptinin teknik imkanlar elverdiğinde neye tekabül ettiğine dair özgün bir tablo sunar:

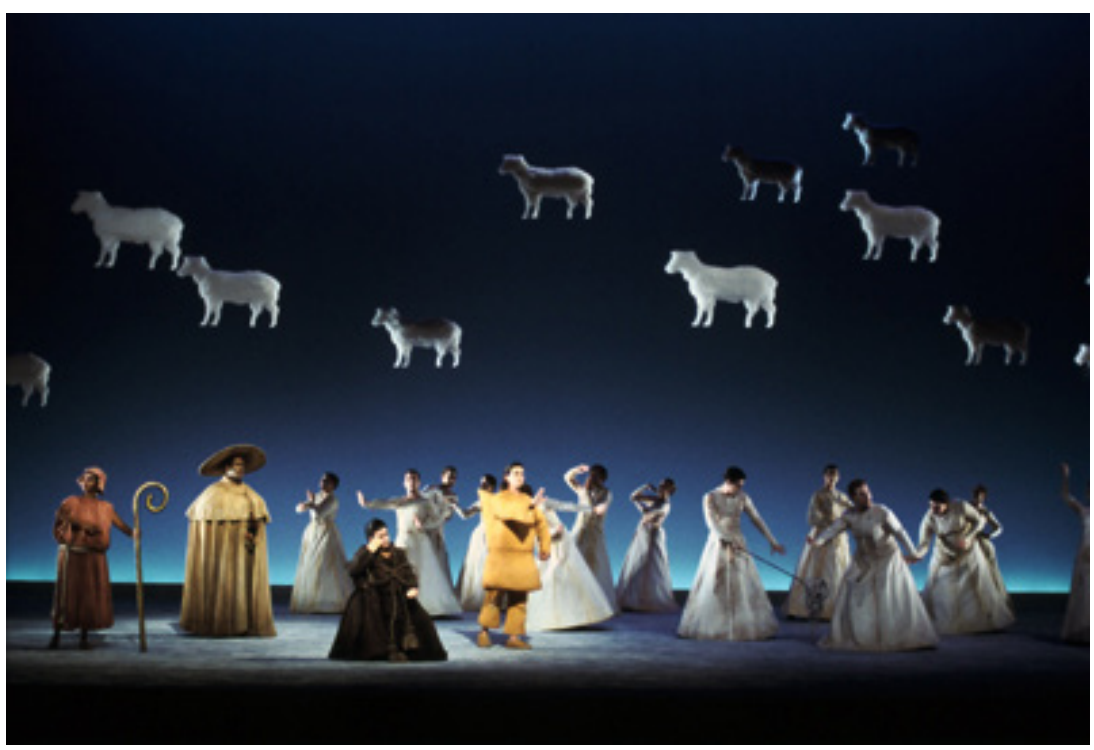

Four Saints in Three Acts, Yönetmen: Robert Wilson, New York State Theater - Lincoln Center, New York, 1996. Fotoğraf: Stephanie Berger. 
Oyun, yazarının masa başında oturduğu bir prolog ile açılır. Masa başındaki yazar az sonra izlenecek olan oyun üzerine çalışmaktadır. Yaratım sürecini görünür kılan meta-anlatılara özgü bu açılış sahnesi bir tür "Las Meninas" [Nedimeler] efekti olarak düşünülebilir. İspanyol ressam Diego Velázquez’in 1656 tarihli tablosu, temsil ve mimesis kavramlarını sorunsallaştırmasıyla bilinmektedir. Saray ressamı Velázquez tablonun sol tarafında yüzü izleyiciye dönük olarak kral ve kraliçeyi resmetmekte, izleyici ressamın üzerinde çalıştığı genişçe tuvali arkadan görmektedir. Resmedilen kral ve kraliçe izleyicinin durduğu yere konumlandırılmıştır; resimde birebir yer almazlar ancak arka taraftaki bir aynaya yansımaları düşer. Michel Foucault, Kelimeler ve Şeyler'de bir ressam olarak Velázquez'in "Las Meninas”taki varlığının, “özne ve nesne, seyirci ve model rollerini sonsuza kadar ters-yüz etmekte" ${ }^{54}$ olduğunu söyler. Foucault'ya göre,

Velâzquez'in bu tablosunda, klasik temsilin temsili gibi bir şey ve açtığı mekânın tanımı vardır. Nitekim, bu mekânın tüm unsurları, imgeleri, kendini sunduğu bakışlar, görünür kıldiğı çehreler, onu doğuran hareketleri bu tabloda temsil etmeye girişmektedir. Fakat, buraya getirdiği ve hepsini birden sergilediği bu dağınıkllğın içinde, özel bir boşluk, her yandan emredici bir şsekilde işaret edilmektedir: onu kuranin zorunlu olarak yok olması -benzediği kişinin ve gözünde benzerlikten ibaret olduğu kişinin-. Bu konumun kendisi-aynıdır-ortadan kaldırılmıştır. Ve sonunda, onu zincire vurmuş olan bu ilişkiden kurtulan temsil, kendini saf temsil olarak verebilir. ${ }^{55}$

Velázquez'in ressam olarak kendini tablosuna yerleştirmesindeki ve Gertrude Stein'ın yazar olarak oyununun açılışını yapmasındaki mantık aynıdır. Stein, birazdan başlayacak olan oyunun fiktifliğine vurgu yapmakta, sahnede belirecek olan peyzajı bir yazar olarak nasıl düzenleyeceğine dair kafa yormaktadır:

Bilmek onu bilmek böylesine sevmek.

Hazırlanın azizler azizler için hazırlanın

[...]

Anlatıda hazırlanın azizler için.

Hazırlanın azizler için.

İki aziz.

Dört aziz.

İki aziz dört aziz için hazırlıyor onu iki aziz azizler için hazırlanır azizler için hazırlan.

Azizler için hazırlığın anlatısı antlatıda hazırlanın azizler için.

Azizler için iki azizin hazırlı̆̆ını anlatmak için kalın

En azından.

Sonuçta.

[…]

Bir aziz iki aziz olacaktır üç olduğunda ve sen beş yap ve iki yeterlidir.

En fazla.

Aziz aziz ve bir aziz.

54 Michel Foucault, Kelimeler ve Şeyler: İnsan Bilimlerinin Bir Arkeolojisi, çev. Mehmet Ali Kılıçbay, (Ankara: İmge Kitabevi, 2001) s. 29.

55 a.e., s. 44. 
Unutulmuş bir aziz.

Bugün ne oldu, bir anlatt. ${ }^{56}$

Klasik temsil ve mimesis yasalarını ters-yüz eden bu açılış, öte yandan "şu-anda-bulunuş" [presence] vurgusunu içerir. İzleyici için oyun metni sahnede işleyen zamanın öncesinde yazılmış bir "tamamlanmış metin" değildir artık; bir süre sonra sahnede olup bitecekler masasının başında oturan yazar tarafindan o anda ve o mekânda oluşturulmaktadır. Şu hâlde yazar bir sahnesel mevcudiyet kazanır ve sahnenin öyküsüne can veren görünmez, kudretli bir otorite olmaktan çıkarak ete kemiğe bürünür: ölçer biçer, karar verir, vazgeçer, düşünür, yazar ve siler. Böylelikle temsilin fiktif niteliği hem görünürlük kazanır hem de kendi kendini değiller. Jane Palatini Bowers'ın da belirttiği gibi yazma eylemi ve performans eşzamanlı ilerlemektedir; dolayısıyla oyun metni "tamamlanmış metin" olmanın ötesine geçerek performansa göre tasarlanan ve asla tam olarak tamamlanmayacak bir plana dönüşür. ${ }^{57}$

Sözü edilen bu açılışın devamında Stein "bugün ne oldu"yu anlatmaya başlar:58 fakat "ne oldu?” sorusunun yanıtı belirsizdir. Klasik anlatılara özgü geçmiş zaman kipine geçilir, güzel bir günde ve koşturmaca içinde, gerçekleştirmeyi umdukları bir sayfiye ziyaretinden söz edilir. ${ }^{59}$ Esasında bu kısım tam olarak ne olduğunun veya nereye gidileceğinin bilgisini içermez: Kişiler oldukları yerde fakat koşuşturmaca içinde; eyleme hâliyle eyleyememe arasında bir yerdedirler:

Güzel bir gün olsaydı kıra gitmeye niyet etmiştik çok güzel bir gündü ve biz de bu niyetimizi gerçekleştirdik. Ayn derecede mutlu olduğumuz zamanlarda gittiğimiz yerlere gittik ve hemen hemen bulabileceğimiz şeyleri bulduk ve dönerken nihayetinde zaten ödüllendirildiklerini gördük ve duyduk. Bu tekrar gitmeyi gerekli hale getiriyor. Geldi ve acele ettiğini acele ettiğini söyledi ki olduğu gibi kalmak için acele ediyordu olduğu gibi kalmak için dedi niyahetinde olmak için dedi ve iddia etti dedi her şeyin hemen hemen eskiden olduğu gibi hissettiğini söyledi sanki değerli olabilicekmiş gibi değerli olabilecekmiş gibi eskiden olduğu gibi eskiden olduğu gibi [...] ve bir toz zerresi ve onun toz zerresi maviye dönüyor onlarınki bir incelik içinde olduğunda paylaşılan ve cevap azalmayla birlikte aynısı oluyor daima aynı saygı içinde hiç değil ve dahası dahası bilinebilir $[\ldots]^{60}$

Stein bu kısmın ardından adeta tekrar azizleri hatırlar ve kendini azizlerin hikayesini başlatmaya zorlar. ${ }^{61}$ Öncelikle hangi azizleri oyuna dâhil edeceğine karar vermelidir. İlk sahneye geçmeden evvel bir azizler listesi çıkarır:

56 Stein, "Four Saints in Three Acts", s. 11.

57 Jane Palatini Bowers, "The Composition That the World Can See: Gertrude Stein's Theater Landscapes", Land / Scape / Theater içinde, ed. Elinor Fuchs \& Una Chaudhuri, (The United States of America: University of Michigan, 2005), s. 133.

58 Jane Palatini Bowers, "They Watch Me as They Watch This": Gertrude Stein's Metadrama, (The United States of America: University of Pennsylvania Press, 1991), s. 39.

59 a.e.

60 Stein, "Four Saints in Three Acts", s. 11-12.

61 Bowers, "They Watch Me as They Watch This": Gertrude Stein's Metadrama, s. 40. 
Herhangi biri herhangi bir aziz olduğunu görebilir.

\begin{tabular}{|c|c|}
\hline Azize Therese & Aziz Ignatius \\
\hline Aziz Matyr & Aziz Paul \\
\hline Aziz Settlement & Aziz William \\
\hline Azize Thomasine & Aziz Gilbert \\
\hline Azize Electra & Aziz Settle \\
\hline Azize Wilhelmina & Aziz Arthur \\
\hline Azize Evelyn & Aziz Selmer \\
\hline Aziz Pilar & Aziz Paul Seize \\
\hline Azize Hillaire & Aziz Cardinal \\
\hline Aziz Bernardine & Aziz Plan \\
\hline Aziz Giuseppe62 & \\
\hline
\end{tabular}

Azizleri ve azizeleri oyuna nasıl yerleştirmesi gerektiğinin planını kurmaya çalışan Stein'in bu çabası tüm oyun boyunca sürer: Kaç aziz vardır, kaç azize vardır, kaç sahne vardır, kaç kapı vardır, kaç pencere olacaktır? Tüm bu sorular oyun boyunca sıklıkla tekrarlanır ve oyunun "azizler planı" oyun süresince sürekli olarak yeniden kurulur. ${ }^{63}$

Kaç perde var içinde. Perdeler içinde.

Üç tekerleğe bir tekerlek daha eklendiğini fark ederek kaç perde kaç perde kaç perde var içinde. Aslında hiç aziz.

Kaç perde var içinde.

Toplamda kaç aziz var.

Kaç perde var içinde.

[...]

Lütfen beni görmeye gelin.

Gördüğ̈̈nüz zaman hepiniz bir bütünsünüz benim için.

Ben yani sen sen doğru olan sen kendine doğru olan.

Kaç tane kaç tane aziz var içinde.

Bir iki üç hepsi dışarı ben kalıyorum.

Bir iki üç dört hepsi dişarı dört kalıyor.

Bir iki benim dışımda hepsi.

Kaç aziz var içinde.

Kaç aziz var içinde.

Kaç perde var içinde.

Bir iki üç dört ve kapı yok, ya da daha ya da hiç biri ya da kapı ya da zemin ya da kapı.

Bir iki üç hepsi dışarı ben kalıyorum. Kaç aziz var içinde. ${ }^{64}$

62 Stein, "Four Saints in Three Acts", s. 15.

63 Bowers, "The Composition That the World Can See: Gertrude Stein's Theater Landscapes", s. 133-134.

64 Stein, "Four Saints in Three Acts", s. 45-46. 
Stein'in yazar olarak sahnede bulunması ve tüm bir temsilin oyun boyunca oluşadurması seyircinin sürekli şimdiki zamanda kalmasını sağlar. Seyirci sahne üzerindeki azizlerle bir aşinalık ilişkisi kurmak durumunda değildir; tüm oyun kişileri peyzaj olarak kurgulanan sahnesel uzamın bir parçasıdır ve oyuna geçmişleriyle değil, sahnesel varlıklarıyla hizmet ederler. Azizler sahne dekorunun bir parçasıdır; dolayısıyla bu düzende oyun kişileri kapılardan veya pencerelerden daha değerli bir konumda değildir. Oyunda kaç aziz olacağına karar vermeye çalışan yazar, kaç pencere ve kaç kapı olacağını da aynı ölçüde önemser. Peyzaj dramaturjisi, sahne üzerindeki canlı ve cansız her bir varlığı birbiriyle olan ilişkisi içinde gözetmekte; eylemi kişilerden çekerek bu ilişkiselliğe teslim etmektedir. Zira devinimi sağlayan, şimdiki zaman içinde ve seyircinin gözü önünde yer değiştirip duran bu ilişkiselliktir; böylelikle olay ve eylem anlatının koşulu olmaktan çıkarak konvansiyonel drama özgü eski önemini yitirir. Bu sayede Gertrude Stein, şimdiki zamanı peyzaj dramaturjisi içinde “izlenebilir” kılmış olur. Stein'in “peyzaj olarak oyun” formülüyle natüralist dramın geçmiş zamana koşullanarak işlettiği sabit çerçeve düzeni ve tablo mantığı çözülmüş; şimdinin takip edilmesi güç deviniminden yeni bir teatral düzen önerisi sunulmuştur.

\title{
3.2. Dil Sorunsalı ve Fenomenoloji
}

\author{
Bir dil dener. \\ Bir dil olmayl dener. \\ Bir dil özgür olmayı dener.
}

-Gertrude Stein, Last Operas and Plays

Gertruda Stein, tarihsel avangardların dile karşı açtıkları savaşı açıktan sürdürmez. Dili tiyatrodan kovmak gibi bir niyet içinde değildir; aksine, yazdığı oyunların her biri söz ve yazının belirlediği bir estetik içinden şekillenir. Bu durum çoğu zaman Stein tiyatrosunun tarihsel avangard özden yoksun olduğu şeklinde yorumlanmıştır. Buna rağmen Stein'in döneme özgü dil, anlam ve temsil tartışmalarıyla ilgilenmediğini, dolayısıyla dile ilişkin eleştirel bir tutum içerisinde olmadığını söylemek mümkün değildir. Aksine, Stein'in tüm sanat yaşamı boyunca konu edindiği temel sorunsaldır dil. Söz ve yazıya dair takındığı tutum tarihsel avangard bir dışlama değildir; çünkü dili alışılageldik kullanımından soyutlayarak tiyatroya özgü bir "araç” hâline getirmekle ilgilenmiştir Stein. Bu anlamda özellikle yazıya yaklaşımının tıpkı Derrida'da olduğuna benzer bir motivasyonla, olumlayıcı bir yönelim içerdiğini söylemeliyiz. Dilin alışılageldik kullanımı ve logosa mahkûm bir hâlde üretilen tiyatro, Stein için de geçersiz kılınması gereken ölü bir temsilden ibarettir. Ancak Stein'e göre dil, yazı içerisinden türetilebilecek olanakların açacağı oyunsu denemelerle üzerindeki ölü toprağını atabilir niteliktedir. Tarihsel avangardların dile karşı açtıkları savaşta dilin bu niteliği ıskalanmıştır ve Stein açıkça bu şekilde ifade etmese de sezgisel olarak bu durumun farkındadır. 
Böyle söylüyorum, çünkü geride bıraktığı oyun metinlerine, anlatı, zaman ve oyun kavramları üzerine yazıp çizdiklerine bakıldığında ortaya çıkan tablo açıktır; zira 1970'li yılların postyapısalcı atmosferi içinde dile dair öne sürülen tezlerin pek çoğu Stein tiyatrosunda farklı biçimlerde de olsa denenmiştir. Söz gelimi, Stein tiyatrosu zaman kavramı üzerine post-yapısalcı teatral denemelerin pek çoğunu öncüleyen bir ilk denemedir. Stein'in zaman üzerine bu kadar çok düşünmüş ve denemiş olmasını Derridacı “bulunuş kipi” tezine ilişkin bir tür önsezi olarak okumak mümkündür. Bu önsezi, yazarın dille kurduğu ilişkinin alışılageldik olandan farklı bir biçimde gelişmesini ve yanı sıra tarihsel avangardların dilin reddiyesi söylemlerine Stein'in doğrudan dâhil olmamasını sağlamıştır.

Stein tiyatrosundaki Derridacı "bulunuş kipi” önsezisi diyerek nereye varmaya çalıştığımı kısaca özetlemek gerekiyor: Okuyucu, Stein'in konvansiyonel bir oyun izlediğinde içini kaplayan sıkıntıyı hatırlayacaktır. Bu sıkıntıyı konvansiyonel drama özgü senkopal uyumsuzluk olarak tarif eden Stein için seyircinin zamanı ile oyunun zamanı farklı akmaktadır; çünkü bu tür bir tiyatroda şimdi geçmişe mahkûm kılınmıştır. Tiyatronun alametifarikası şimdi ve burada olmaklıkken, Batılı tiyatro bu niteliğini yazıya olan bağımlılık derecesindeki saplantısı yüzünden başkalaştırmak durumunda kalmıştır. Konvansiyonel tiyatro yazıya, üstelik yazının sahip olduğu tüm olanakları köreltecek bir kullanımla bağımlıdır. Olanaklar körelmiştir, zira bu kullanımda yazı ancak yazarının - oyuncu tarafından aktarılan- sesi olarak vardır. Böylece dil ölü bir temsile dönüşür; çünkü hem söz hem de yazı kendi özerkliğini yitirmiştir. İşte Stein, bu noktada konvansiyonel tiyatronun zaman kavrayışının dille olan ilişkisinde doğrudan bir belirleyen olduğunu sezmektedir: Batı tiyatrosu zaman ve dil ile olan ilişkisini bu şekilde kurduğu müddetçe, söz ve yazı ölü bir temsil olmanın ötesine geçemez; üstelik tiyatronun alametifarikası dediğimiz şimdi ve burada olmaklık, özünden vermeye ve büyüsünü yitirmeye başlar.

Yine hatırlanacak olursa, tüm bir tarihsel avangardın söze karşı takındığı negatif tavır, logos etrafında şekillenen Batı tiyatrosunun eleştirisi olarak başlamıştır. Tarihsel avangardlardan yaklaşık 40 yıl sonra yazacak olan Derrida içinse logosun bulunuş kipi sözdür ve Batı düşününe özgü bulunuş kipi her daim bir ikilik üzerinden işler. Bu ikiliği sekteye uğratabilmek ancak yazının dilde açabileceği gedikler, diğer bir deyişle oyun alanları sayesinde mümkündür. Böyledir, çünkü söz şimdi ve burada olmaklık dışında var olamaz ve bir konuşana ihtiyaç duyarken yazı bu anlamda bulunuş kipine mahkûm değildir. Yazı tekrar edilebilirlik niteliğine sahiptir: bir kere yazılması kâfidir; varlığını sürdürebilmek için yazarına bağımlı değildir. Yazıldıktan sonra onu yazandan bağımsızlaşarak tekrar tekrar okunmak üzere sonsuz bir dolayıma girer.

Stein'in dili kullanımı da bu türden bir tekrar mantığı üzerinden işler. Konvansiyonel tiyatroya özgü zaman ve bulunuş kipi kullanımını aşmak üzere dildeki tekrarlar üzerinden geliştirdiği formül, tiyatroda yazının o vakte dek sabitlenmiş değerini ve işlevini değiştirir. Yazı artık salt metin yazarının sahnedeki oyuncu ağzından dökülen sözleri olmaktan çıkarak 
tiyatronun etkin bir öğesi hâline gelir: Söz ve yazı arasındaki hiyerarşi ortadan kalkar ve dil sahnede en az oyuncu kadar varlık göstermeye başlar. Stein, Batı tiyatrosuna dair sezinlediği pek çok sorunu yazının tekrar edilebilirlik niteliği sayesinde aşabileceğinin farkındadır ve bu yolla esasında tiyatronun konvansiyonunu yapısökümüne uğratmaktadır. Oyun içinde aynı cümleye ve hatta "Civilization" [Medeniyet] oyununda olduğu gibi aynı sahneye tekrar tekrar başlayarak konvansiyonel drama özgü zamanı askıya alır. Böylelikle çizgisel zamanın başlangıç-bitiş gereksinimi ortadan kalkar ve oyun bulunuş kipine ait sürekli şimdiki zamana sabitlenir.

\section{PERDE \\ Çok kolaylıkla unutulur. Kim gidiyordu. Kolaylıkla unutulduğundan. Kim iyiydi. Kolaylıkla unutulduğundan. Jenny William. Ve kolaylıkla unutulduğundan. Jenny. William. \\ III. PERDE \\ Kolaylikla unutulduğundan. Jenny William. \\ Kolayllkla unutulduğundan. Herhangi bir para. \\ Kolaylıkla unutulduğundan. Mantarlar. \\ Kolaylıkla unutulduğundan ve Jenny William.65}

Öte yandan Stein tiyatrosundaki fenomenolojik soruşturma yine söz konusu tekrarlarla sağlanır: seyircinin dikkati dünyayı kavrayışın bir aracı olarak dilin kendisine çekilmektedir ve tekrarlar, Terry Castle'ın da söylediği gibi, seyirciyi “dünyaya yeni ve daha dolaysız bir yolla bakmaya zorlar". ${ }^{66}$ Böylesi bir kullanım, dili tüm yapısı ve yapı içindeki olanaklarıyla sahnede görülebilir ve duyulabilir bir öğe hâline getirir. Stein sahnede adeta "dilbilgisigrameri üzerine bir tez" yazmaktadır ve tezinin sorunsalı "dilbilgisinin insan yaşamıyla olan ilişkisidir". ${ }^{67}$ Stein, olayları klasik anlatı ve dil kalıpları içinde aktarmak yerine olayların özüne, nesnelerin birbiriyle olan ilişkiselliğine odaklanmaktadır ve dil bu noktada sabit “öz”leri kendi dünyasallıkları içinde çeşitlemeye yarayan bir araç olarak öne çıkar.

Fenomenoloji düşüncesinin temellerini atan Alman filozof Edmund Husserl'e göre, hayal gücünde çeşitleme yöntemi kişiye nesnenin bizzat özünü, varlığını verir. ${ }^{68}$ Lyotard'ın aktarımıyla, nesne "herhangi bir şey"dir ve bu şey, keyfi olarak, bağlamının güncel ve yaşanan delillerine itibar edilerek "çeşitlenir". ${ }^{69}$ Nesnenin özü ya da eidos' $u$, bu çeşitlemeler boyunca hep aynı kalan değişmezden ibarettir. Örneğin çeşitleme operasyonunu algılanan şey-nesne üzerinde

65 Gertrude Stein, "Civilization”, Operas \& Plays içinde, (New York: Station Hill Press, 1987), s. 152-153.

66 Terry Castle'dan aktaran: Marjorie Perloff, "Grammar in Use: Wittgenstein/Gertrude Stein/Marinetti”, South Central Review, 13, 2/3, (1996), s. 61.

67 a.e., s. 44.

68 Edmund Husserl'dan aktaran: Jean-François Lyotard, Fenomenoloji, çev. İsmet Birkan, (Ankara: Dost Kitabevi Yayınları, 2007), s. 19.

69 a.e., s. $19-20$. 
yaparsak, şeyin bizzat varlığını elde ederiz: töz ve nedensel birim olarak konmuş, ikincil niteliklerle donanmış bir uzay-zamansal bütün... Demek ki öz, yaşanmış bir sezgide sınanır; “özlerin görülüşünün” (Wesenschau) hiçbir metafizik niteliği yoktur, özler kuramı, özün varoluşunun olumlanacağı Platoncu bir kavram realizmi çerçevesine girmez; öz sadece, içinde “şeyin kendisinin” kökensel bir veriliş içinde bana açımlandığı şeydir. ${ }^{70}$

Bir röportajında söylediğine göre, önce masanın üzerine herhangi bir nesne yerleştirip nesneye dair zihninde canlanan pür imgeyi aklından çıkarmaya çalışan Stein, sonra kelime ve gördüğü şey arasında sözcüksel bir ilişki yaratmaya yoğunlaşırmış. ${ }^{71}$ Şayet Stein'in bu çabası “özlerin görülüşünü yaşanmış bir sezgide sınamak” olarak düşünülürse, yazarın söz konusu sınamayı dil vasıtasıyla çeşitlemeye çalıştığı ve nesnenin bizatihi varlığını dil ile açımlamaya uğraştığı pekâlâ söylenebilir. Marjorie Perloff'un da belirttiği gibi, Stein'in dili kullanarak yaptığg bu denemeleri Wittgenstein'1n Felsefi Soruşturmalar'da öne sürdügü fikirlerle ${ }^{72}$ fenomenolojik bir bağlamda- okumak da mümkündür. "Bir sözcüğü anladığımızda gerçekten aklımıza ne gelir? O bir resim gibi bir şey değil midir? O bir resim olamaz mı?"’3 diye soran Wittgenstein şöyle söylemektedir:

Anlamada başarısız oluşumuzun bir ana kaynağl, sözcüklerimizin kullanımının net bir görünüşüne hâkim olmamamızdır. Bizim dilbilgimiz bu tür açıklıktan yoksundur. Açık bir tasarım, tamamen 'băğntıları görme'den ibaret olan anlamayı ortaya çıkarır. Böylelikle de ara durumları bulma ve yaratmanın önemini. ${ }^{74}$

O hâlde Stein sözcükleri kullanarak tiyatroyu açık bir tasarım (peyzaj) gibi kurgulamakta ve "bağıntıları görmeye" odaklanmaktadır. Konvansiyonel tiyatronun dili ve grameri bu bağıntıları gösterecek açıklıktan yoksun, kapalı ve sistemli bir yapıdır. Öte yandan dil, tam da grameri sayesinde pek çok açıklık yaratabilme olanağına sahiptir. Eğer bu gramer ilişkisellikleri görmeyi, ara durumları fark edebilmeyi sağlayacak şekilde kuraldışı bir biçimde kullanılırsa olayların özü bir anlık da olsa görülebilir, hissedilebilir, sezinlenebilir bir hâl alır.

Başa dönersek, "Bir dil dener / Bir dil olmayı dener / Bir dil özgür olmayı dener"75 diye yazan Stein'in formülü, "kimi kelime ve ifadeleri yerinden ederek diğerlerini yerine oturtmak" grameri kuraldışı kullanarak açıklık yaratmaktır ve Stein'dan neredeyse 40 yıl sonra Derrida bunu yapısöküm olarak tarif edecektir.

70 a.e., s. 20 .

71 Stein'den aktaran: Perloff, “Grammar in Use: Wittgenstein/Gertrude Stein/Marinetti”, s. 42.

72 a.e., s. 41.

73 Ludwig Wittgenstein, Felsefi Soruşturmalar, çev. Deniz Kanıt, (İstanbul: Totem Yayıncılık, 2006), s. 75.

74 a.e., s. 69.

75 Gertrude Stein, Last Operas and Plays, ed. Carl Van Vechten, (New York: Rinehart, 1949), s. 153.

76 Perloff, "Grammar in Use: Wittgenstein/Gertrude Stein/Marinetti”, s. 42. 


\section{Sonuç}

Modernist edebiyatın mihenk taşlarından biri olarak kabul edilen yazar, şair ve sanat koleksiyoncusu Gertrude Stein, tarihsel avangard sürecin en ilham verici figürleri arasındadır. Ellinin üzerinde ${ }^{77}$ oyun yazmış olmasına rağmen Stein'ın oyun yazarlığg üzerine çokça çalışılmamış olması, oyunlarının sahnelenebilir bulunmayışı genel kanısıyla açıklanabilir ancak. Gertrude Stein oyunları, genellikle okunmak için yazılmış oyunlar kategorisinden sayılmaktadır. Söz gelimi Jane Palatini Bowers'a göre Stein oyunları tiyatro için yazılmış değildir; ancak tiyatro üzerinedir. ${ }^{78}$ Benzer bir şekilde Martin Puchner, Stein'in dramatik metinlerini okuma tiyatrosu [closet drama] kategorisine dâhil etmenin doğru olacağını söyler ve fakat Four Saints in Three Acts [Üç Perdede Dört Aziz] oyununa "sahnelenmek üzere bir okuma tiyatrosu" şeklinde bir şerh düşer. ${ }^{79}$ Betsy Alayne Ryan ve Sarah Bay-Cheng gibi Stein araştırmacılarına göre ise söz konusu oyunları salt okuma tiyatrosu şeklinde ele almak doğru değildir; çünkü bu oyunlar sahnelenmek üzere yazılmış tiyatro metinleri, diğer bir deyişle performans metinleridir. Sarah Bay-Cheng'e göre Stein oyunlarının hem drama hem de tiyatro kümesi içinde değerlendirilmesi gerekmektedir. Zira Stein'in tiyatro düşüncesi hem Amerikan deneysel performansına hem de Amerikan dramatik literatürüne doğrudan yön vermiştir. ${ }^{80}$ "Çizgisel olmayan olay dizisi, tekrarlamalar, parçalı (veya bütünüyle tasnif edilmiş) karakterler, eşzamanlılık ve kendine özgü sürekli şimdiki zaman" "81 kullanımlarıyla Gertrude Stein oyunları dramatik konvansiyonun bütünüyle dışındadır. Döneminin alışılagelmiş tiyatro anlayışını topyekûn reddeden Stein'ın bir oyun yazarı ve bir tiyatro vizyoneri olarak -Robert Wilson, Richard Foreman, Judith Malina, Heiner Goebbels gibi- çağdaş yönetmenler üzerindeki etkisi azımsanmayacak ölçüdedir.

Tarihsel avangardlarla birlikte tiyatroda görülen metin-karşıtı tavır, söz konusu Gertrude Stein olduğunda tersinden işler. Stein, bir oyun yazarı olarak asla dilden ve dolayısıyla metinden vazgeçmemiştir. Bu durum çoğu zaman Stein'in tarihsel avangard drama kategorisinin dişında tutulmasına sebep olmuştur. Örneğin Christopher Innes avangard tiyatronun öğelerinden söz ederken "teatral dilin yeni formu” ifadesini kullanır ve sözünü ettiği bu yeni dilin her türlü yazılı metninden bağımsız düşünülmesi gerektiğini söyler. ${ }^{82}$ Gertrude Stein üzerine çalışan Jane Palatini Bowers ise tarihsel avangardlar için metnin öneminin asgari düzeyde olduğunu ve tarihsel avangardlarca yazılmış tiyatro metinlerinin her zaman ve her şekilde karşı-yazınsal

77 Wilford Leach, Gertrude Stein oyunlarının sayısı hakkında net bir bilgi vermenin mümkün olmadığını, çünkü yazarın diğer pek çok metnini de "oyun" olarak adlandırmayı tercih ettiğini ifade eder. Wilford Leach, Gertrude Stein and Modern Theatre, s. 2. Ferdi Çetin ise Richard Bridgman ve Betsy Alayne Ryan'ın çalışmalarına göre derlediği kronolojik listeye 77 oyun dâhil eder. Çetin, ““'Continuous Present” in Gertrude Stein's Plays”, s. 70-75. Jane Palatini Bowers'tan aktaran: Bay-Cheng, Mama Dada: Gertrude Stein's Avant-Garde Theater, s. 3.

79 Bay-Cheng, Mama Dada: Gertrude Stein's Avant-Garde Theater, s. 3.

80 a.e., s. 3-4.

81 a.e., s. 18.

82 Christopher Innes'ten aktaran: a.e., s. 48. 
nitelik taşıdığgnı iddia eder. ${ }^{83}$ Sarah Bay-Cheng, Gertrude Stein oyunlarının metin-karşıtı bir nitelik taşımadığını açıkça kabul eder: "dilde yaptığı radikal denemelerine rağmen Stein 1srarla yazılı dile ve metni merkeze almaya sadık kalmıştır." ${ }^{4}$

Cheng, "açıkça söylenmese de Stein'in asla tam olarak tarihsel avangardlar kümesine dâhil edilmeyişine" ${ }^{" 85}$ dikkat çeker ve bu durumun sebepleri üzerinde durur. En temel gerekçe elbette yazarın tarihsel avangardların karşı-yazınsal tavrını benimsemeyişidir. Cheng, ikinci gerekçe olarak Stein yazınının eleştirmenler tarafından tarihsel avangard ideolojiye özgü politik tondan yoksun bulunmasını gösterir. Jane Palatini Bowers’tan alıntılar:

Stein oyunlarl, tüm diğer muhalif avangardlar gibi, bize alışılagelmişin dışında ve yabancılaşma olană̆ tanıyan bir tiyatro deneyimi sunmasına rağmen, bana göre, karşı veya nihilist bir tavır içermez. Sürrealistler seyirciyi terörize ederken, Dadaistler rencide ederken ve Fütüristler şok ederken, Stein seyirciyi oyun esnasında rahatsiz etmeyecek bir tiyatro deneyimi sunmayı arzuluyordu. 86

Cheng, son olarak, eleştirmenlerin Stein'1 avangard oyun yazarlarından ziyade avangard ressamlarla ilişkilendirme eğiliminde olduklarına işaret eder: Andrej Wirth'e göre "kişi bir Stein oyunu karşısında Picasso'nun, Braque'ın ya da Heartfield'ın kolajları karşısında duyduğu belirsizlik hissine kapılır." ${ }^{87}$ Even Marc Robinson'a göre "Stein oyunlarında 'eylem' ve 'sahneler', algılanan dünyanın farklı bölümlerine dikkatimizi yönlendiren resimlerin çerçeveleri gibi işler." ${ }^{" 8}$ Cheng, tarihsel avangardın resim kanalıyla Gertrude Stein arasında kurulan paralelliklerin isabetli olduğunu söyleyecektir; ${ }^{89}$ zira bir sanat koleksiyoncusu olarak Stein'in dönemin önde gelen ressamlarıyla olan etkileşimi çok açıktır. Fakat Cheng'e göre tüm bu tespitlerde 1skalanan nokta, "kolaj kullanımı ve çerçeve düzeninin salt görsel sanatlarla sınırlı olmayışıdır." 90

Gertrude Stein tarihsel avangard oyun yazarlarının "karşıt" tavrını aynı yönelimler üzerinden benimsemez. Martin Puchner'e göre Stein, karşıt avangard değerlerle değil yüksek modernizmin içe kapanmayı yücelten (karşı-teatral) değerleriyle düşünülmeli; avangard Tristan Tzara'nın değil modernist Mallarme'ın yolundan yürüyen bir yazar olarak ele alınmalıdır. ${ }^{91}$ Açıktır ki dilden vazgeçmeyişi ve metni dışlamayışından dolayı Gertrude Stein, yazılı metinden bağımsız

83 Jane Palatini Bowers'tan aktaran: a.e., s. 49.

84 a.e., s. 48.

85 a.e., s. 49.

86 Jane Palatini Bowers'tan aktaran: a.e., s. 49.

87 Andrej Wirth'ten aktaran: a.e., s. 49.

88 Even Marc Robinson'dan aktaran: a.e., s. 49.

89 a.e., s. 49

90 a.e., s. 49.

91 Martin Puchner, Stage Fright: Modernism, Anti-Theatricality, and Drama, (Baltimore \& London: The Johns Hopkins University Press, 2002), s. 116. 
yeni bir sahne dili oluşturma fikri üzerinden teatrallik kavramını olumlayan tarihsel avangard içinde değerlendirilmemektedir. Bu yaklaşımın belirli yönleriyle isabetli olduğu kuşkusuz; fakat Stein'1 dilden vazgeçmeden yazdığı için okuma tiyatrosu kategorisi içerisinden düşünmek, bugünden geriye doğru bakıldığında çokça yerinde bir tespitmiş gibi durmuyor.

Her şeyden önce, bir oyun yazarı olarak Stein dili ve metni dışlamadan yazmakta, buna rağmen dramatik konvansiyonun altını açıkça oymaktadır. Tarihsel avangardların metinkarşıtlığı hiç kuşkusuz temsil olanağına inanan dramatik geleneğe karşı bir tavırdır. Gertrude Stein, dramatik konvansiyonun temsil esasını tümden yok saymakta, anlatıyı parçalamakta, zaman kurgusunu dağıtmakta ve natüralist anlamda bir tablo oluşturmak nosyonunu öne sürdüğü peyzaj metin [landscape text] kavramıyla yeniden ele almaktadır. Dolayısıyla Stein oyunlarının yeni-teatral bir estetik önermediğini söylemek hatalı olur. Tam da bu sebeple, tarihsel avangardtan beslenen 1970 sonrası yeni-avangard tiyatro estetiği için Gertrude Stein önemli bir figürdür. Dili reddetmeden dil düşüncesinin üstüne giden yazar, oyunlarında fenomenolojik bir sorgulama içindedir.

Hakem Değerlendirmesi: Dış bağımsız.

Çıkar Çatışması: Yazar çıkar çatışması bildirmemiştir.

Finansal Destek: Yazar bu çalışma için finansal destek almadığını beyan etmiştir.

Peer-review: Externally peer-reviewed.

Conflict of Interest: The author has no conflict of interest to declare.

Grant Support: The author declared that this study has received no financial support.

\section{KAYNAKÇA / BIBLIOGRAPHY}

Abbot, H. Porter. The Cambridge Introduction to Narrative. New York: Cambridge University Press, 2008.

Alfandary, Isabelle. "Page-Landscapes in the Theater of Gertrude Stein", Reflective Landscapes of the Anglophone Countries. Ed. Pascale Guibert. Amsterdam-New York: Rodopi, 2011.

Aristoteles. Poetika. Çev. İsmail Tunalı. İstanbul: Remzi Kitabevi, 1987.

Aronson, Arnold. American Avant-Garde Theatre: A History. New York: Routledge, 2007.

Artaud, Antonin. Tiyatro ve İkizi. Çev. Bahadır Gülmez. İstanbul: Yapı Kredi Yayınları, 1993.

Aydoğdu, Hüseyin. "Maurice Merleau-Ponty’nin Fenomenolojik Ontolojisi”. Doktora tezi, Atatürk

Üniversitesi, 2010.

Bay-Cheng, Sarah. Mama Dada: Gertrude Stein's Avant-Garde Theater. New York \& London: Taylor \& Francis e-Library, 2005.

Bowers, Jane Palatini. "The Composition That the World Can See: Gertrude Stein's Theater Landscapes", Land / Scape / Theater. Ed. Elinor Fuchs \& Una Chaudhuri. The United States of America: University of Michigan, 2005, s. 121-144. 
Bowers, Jane Palatini. "They Watch Me as They Watch This": Gertrude Stein's Metadrama. The United States of America: University of Pennsylvania Press, 1991.

Çetin, Ferdi. ““'Continuous Present”in Gertrude Stein’s Plays”. Yüksek Lisans tezi, Istanbul Üniversitesi, 2013.

Çınar, Cem. "Film Estetiğinde Gerçekçi Sinemanın Fenomenolojisi”. Doktora tezi, İstanbul Üniversitesi, 2014.

Frank, Adam. "Loose Coordinations: Theater and Thinking in Gertrude Stein", Science in Context 25 (3), (2012), s. 447-467.

Freytag, Gustav. Freytag's Technique of Drama: an exposition of dramatic composition and art. Çev. Elias MacEwan. The Internet Archive: 2007, erişim 25 Ocak 2020. https://archive.org/details/ freytagstechniqu00freyuoft/page/n3

Foucault, Michel. Kelimeler ve Şeyler: İnsan Bilimlerinin Bir Arkeolojisi. Çev. Mehmet Ali Kılıçbay. Ankara: İmge Kitabevi, 2001.

Leach, Wilford. "Gertrude Stein and Modern Theatre”. Doktora tezi. University of Illinois, 1954.

Lyotard, Jean-François. Fenomenoloji. Çev. İsmet Birkan. Ankara: Dost Kitabevi Yayınları, 2007.

Merleau-Ponty, Maurice. Algının Fenomenolojisi. Çev. E. Sarıkartal \& E. Hacımuratoğlu. İstanbul: İthaki Yayınları, 2017.

Nişanyan, Sevan. "Senkop", Nişanyan Sözlük: Çağdaş Türkçenin Etimolojisi. 2012-2017, erişim 26 Mart 2018 http://www.nisanyansozluk.com/?k=senkop

Perloff, Marjorie. “Grammar in Use: Wittgenstein/Gertrude Stein/Marinetti”, South Central Review, 13 - 2/3, (1996), s. 35-62.

Puchner, Martin. Stage Fright: Modernism, Anti-Theatricality, and Drama. Baltimore \& London: The Johns Hopkins University Press, 2002.

Scholes, Robert. "Language, Narrative, and Anti-Narrative", Critical Inquiry, 7, (1980), s.204-212.

Stein, Gertrude. Everybody's Autobiography. New York: Vintage Books, 1973.

Stein, Gertrude. "Four Saints in Three Acts", Operas \& Plays. New York: Station Hill Press, 1987, s. 11-47.

Stein, Gertrude. Last Operas and Plays. Ed. Carl Van Vechten. New York: Rinehart, 1949.

Stein, Gertrude. Ne Oldu. Çev. Ferdi Çetin. Yayınlanmamış çeviri.

Stein, Gertrude. "Plays", Look at Me Now and Here I Am: Writings and Lectures 1909-45. London: Penguin Books, 1990, s. 59-83.

Stein, Gertrude. “Civilization”, Operas \& Plays. New York: Station Hill Press, 1987, s. 131-160.

Watson, Dana Cairns. Gertrude Stein and the Essence of What Happens. United States of America: Vanderbilt University Press, 2005.

Wittgenstein, Ludwig. Felsefi Soruşturmalar. Çev. Deniz Kanıt. İstanbul: Totem Yayıncılık, 2006. 
